\title{
Sodobni problemi aplikacije geografije v tematski kartografiji
}

\author{
Drago Perko \\ Dr., Geografski inštitut Antona Melika, Znanstvenoraziskovalni center SAZU, \\ Gosposka 13, 1000 Ljubljana, Slovenija \\ e-mail: drago@zrc-sazu.si
}

\section{Izvleček}

Tematski zemljevid je lahko geografska aplikacija sam po sebi ali pa je temelj drugi geografski aplikaciji. Razvoj slovenske tematske kartografije je izrazito pospešila osamosvojitev države leta 1991. V vsebinskem in tehnološkem pogledu sta največji dosežek Geografski atlas Slovenije in Nacionalni atlas Slovenije, ki sta izjemna tudi na svetovni ravni in pomenita veliko promocijo Slovenije ter slovenske geografije in kartografije. Hiter razvoj spremljajo številni problemi, med njimi tudi (ne)upoštevanje različnih slovenskih in mednarodnih predpisov pri pripravi zemljevidov, kot so na primer resolucije OZN, mednarodni in slovenski standardi (SIST ISO) ter Zakon o avtorski in sorodnih pravicah.

Ključne besede: geografija, kartografija, tematska karta, standard, resolucija, avtorska pravica, Slovenija

\section{Thematic Cartography as a Geographical Application}

\begin{abstract}
A thematic map may be a geographical application (tool) in itself or the basis for some other geographical work. The development of Slovene thematic cartography accelerated considerably following the independence of the country in 1991. From the viewpoint of content and technology, its greatest achievements are the Geographical Atlas of Slovenia and the National Atlas of Slovenia, which are outstanding achievements at the international level and of great significance for the promotion of Slovenia and Slovene geography and cartography. However, this rapid development has been accompanied by numerous problems, for example, the ignoring of various Slovene and international conventions for the preparation of maps including United Nations resolutions, Slovene and international standards (SIST ISO), and copyright laws.
\end{abstract}

Key words: geography, cartography, thematic map, standard, resolution, copyright, Slovenia 


\section{UVOD}

Kartografija je za geografijo in številne druge znanosti pomožna stroka. Mednarodna kartografska zveza (International Cartographic Association) jo je leta 1973 opredelila kot umetnost, znanost in tehnologijo izdelovanja zemljevidov ter preučevanja zemljevidov kot znanstvenih in umetniških del, leta 1995 pa kot disciplino, ki se ukvarja s snovanjem, izdelovanjem, širjenjem in preučevanjem zemljevidov.

Njen predmet preučevanja in hkrati najpomembnejši izdelek so zemljevidi ali karte (italijansko carta 'papir, dokument' iz latinsko charta 'papir, spis' iz grško khártēs 'papirusov list, zvitek'), to so dvorazsežnostni prikazi različnih pojavov na zemeljskem površju ali drugih nebesnih telesih. Delimo jih na splošne (splošnogeografske) zemljevide in posebne (tvarinske, snovne) zemljevide. Na splošnem zemljevidu ali topografski karti so vse sestavine oziroma vsebine prikazane razmeroma enakovredno, na posebnem zemljevidu ali tematski karti pa so nekatere prikazane poudarjeno, druge pa sploh ne. Kakovostni zemljevidi imajo znanstveno in umetniško (estetsko) vrednost.

Za geografijo so še posebej pomembni tematski zemljevidi, saj raziskovalcem geografom pomagajo pri delu kot vir podatkov oziroma obstoječega znanja in omogočajo nazornejše prikazovanje rezultatov njihovih raziskav, učiteljem geografom pa olajšujejo prenašanje znanja na učence.

Zemljevidi so lahko objavljeni kot:

- samostojna publikacija, največkrat na listu večjega formata, pogosto s spremnim besedilom, grafičnimi prilogami in imenikom zemljepisnih imen na hrbtni strani zemljevida (na primer šolska zemljevida Slovenije in Sveta s predstavitvijo slovenskih pokrajin oziroma celin in oceanov na hrbtni strani) ali s priloženo razlagalno knjižico (na primer Vegetacijska karta gozdnih združb Slovenije ali Zgoščeni imenik zemljepisnih imen Slovenije),

- kot zbirka (atlas), največkrat oblikovno enotnih in vsebinsko povezanih zemljevidov, vezanih v knjigo ali spetih (zloženih) v mapo, pogosto s spremnimi študijami $\mathrm{v}$ obliki poglavij in imenikom zemljepisnih imen (na primer Nacionalni atlas Slovenije in Slovenija na vojaškem zemljevidu 17631787),

- kot sestavine drugih avtorskih del (na primer člankov, monografij, filmov, posterjev, učbenikov).

Zemljevidi spremljajo človeka že več tisočletij. Leta 1963 je britanski arheolog James Mellaart (1925-) pri odkopavanju ostankov neolitskega naselja Çatal Höyük (slovenjeno Čatal Hejik)v Turčiji odkril slike na stenah notranjosti svetišča, ki prikazujejo načrt naselja s tlorisi okrog osemdeset zgradb na pobočnih terasah, iznad katerih se dviga gora $\mathrm{z}$ oblakom dima in pepela nad 
vrhom in ognjeniškimi bombami po pobočju. Gora naj bi bila $3268 \mathrm{~m}$ visok ognjenik Hasan Dağı (slovenjeno Hasan Dagi), ki stoji ob vzhodnem robu pokrajine Konya Ovas1, ravnine severovzhodno od mesta Konya, okrog 200 km južno od turškega glavnega mesta Ankare (Perko 2001a). Slike, ki so po Mellaartovem prepričanju najstarejši do zdaj odkriti zemljevid, so bile po radioogljikovi metodi narisane med letoma 6300 in 6100 pr. n. št. (Smith 1987, str. 73). To naj bi bila tudi prva tematska karta. Vsebina zemljevida je prikaz izbruha ognjenika in nekaterih posledic te naravne nesreče.

Slika 1: Stenske slike v notranjosti svetišča neolitskega naselja Çatal Höyük v Turčiji, narisane okrog leta 6200 pr. n. št., naj bi bile najstarejši zemljevid na svetu in hkrati tudi prva tematska karta. Vsebina zemljevida je prikaz izbruha ognjenika in nekaterih posledic te naravne nesreče. Na sliki je osrednji del prerisa izvirnika.

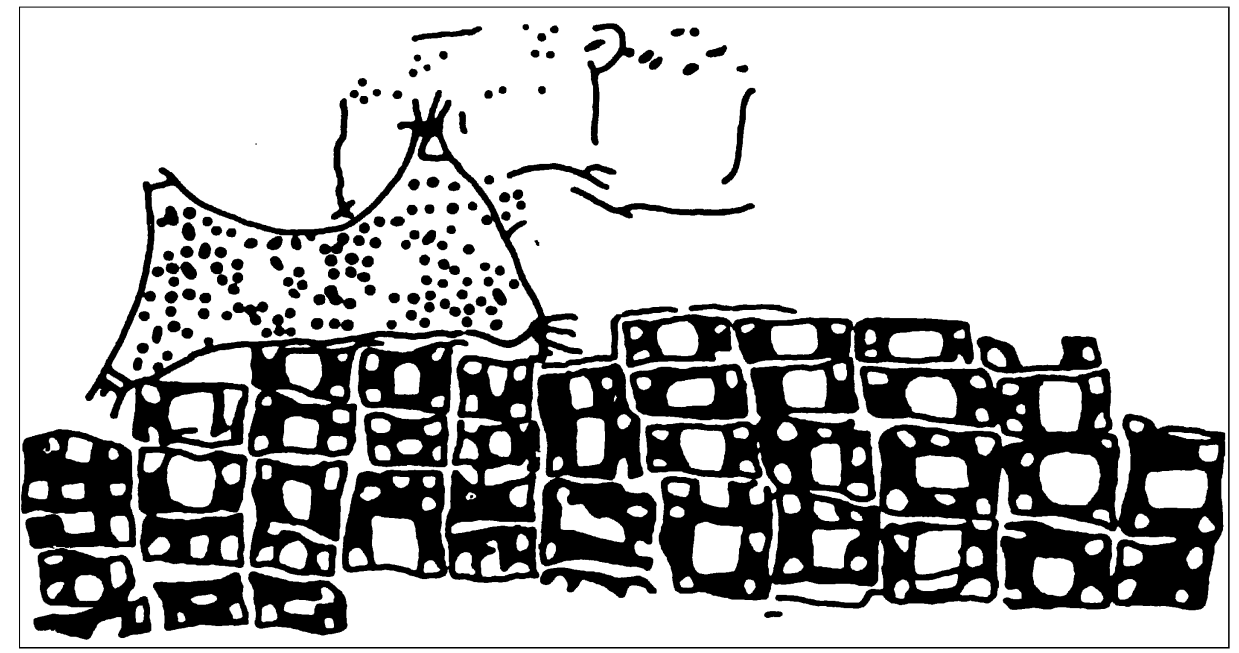

Slovenska institucionalna kartografija je neprimerno mlajša. Uradno se je začela 7. februarja 1952, ko je Slovenska akademija znanosti in umetnosti v okviru Geografskega inštituta ustanovila Kartografski zavod, ki se zdaj imenuje Oddelek za tematsko kartografijo Geografskega inštituta Antona Melika ZRC SAZU (Natek, Perko 1999). Sprva je zavod izdeloval predvsem tematske karte za akademika Antona Melika in Svetozarja Ilešiča, ki sta že pred pol stoletja spoznala pomen kartografskega izražanja, predvsem tematskih zemljevidov za predstavitev znanstvenih dosežkov v geografiji in sorodnih znanstvenih disciplinah, pozneje pa se je njegova dejavnost močno razmahnila. Razvoj tematske kartografije je v Sloveniji izrazito pospešila osamosvojitev 
države leta 1991, ko so se potrebe po tematskih zemljevidih močno povečale. $\mathrm{V}$ devetdesetih letih so državne in privatne ustanove sofinancirale več obsežnejših projektov, ki so se sklenili z izdajo monografij, v katerih so bile objavljeni številni tematski zemljevidi. V vsebinskem in tehnološkem pogledu sta največji dosežek slovenske tematske kartografije Geografski atlas Slovenije s široko uporabnostjo na številnih področjih, in Nacionalni atlas Slovenije, ki je glede na kakovost izjemen tudi na svetovni ravni in pomeni veliko promocijo Slovenije ter slovenske geografije in kartografije v tujini. Tudi slovenski geografski in drugi učbeniki, ki so izšli na koncu 20. stoletja, so izjemno bogato opremljeni z zemljevidi.

Hiter razvoj pa ni odpravil številnih problemov slovenske kartografije. Med največjimi problemi so:

- šolanje kartografov,

- zaposlovanje kartografov,

- financiranje kartografov,

- uvrščanje kartografskih vsebin v učne programe na vseh stopnjah,

- znanstveno in cenovno vrednotenje izdelave avtorskih originalov zemljevidov,

- znanstveno, umetnostno in cenovno vrednotenje izdelave končnih zemljevidov,

- ugotavljanje primernosti zemljevidov za posamezne starostne stopnje uporabnikov,

- varovanje avtorstva zemljevidov,

- zakonsko urejanje avtorske pravice,

- uporabljanje tematskih zemljevidov v elaboratih, knjigah, učbenikih in drugih publikacijah,

- kakovostno tiskanje tematskih zemljevidov,

- objavljanje tematskih zemljevidov na internetu,

- dostopnost podatkov za pripravljanje avtorskih originalov zemljevidov,

- standardizacija zemljepisnih imen,

- razvijanje digitalne tematske kartografije,

- povezovanje geografskih informacijskih sistemov in digitalne tematske kartografije,

- sodelovanje med geografskimi ustanovami na tem področju,

- sodelovanje med geografskimi, geodetskimi in sorodnimi ustanovami na tem področju,

- mednarodno sodelovanje na tem področju.

Pri apliciranju oziroma prikazovanju dosežkov geografskih raziskav na tematskih zemljevidih je vse bolj pereč problem (ne)upoštevanja različnih predpisov oziroma dokumentov na različnih stopnjah, kar je pogosto povezano s trojnos- 
tjo zemljevidov kot znanstvenih, umetniških in tehnoloških izdelkov. Predpisi oziroma dokumenti so lahko:

- obvezujoči (na primer zakoni) in

- neobvezujoči oziroma priporočilni (na primer standardi in resolucije).

V Sloveniji so za kartografe pomembni predvsem Zakon o avtorski in sorodnih pravicah kot obvezujoči dokument ter 167 resolucij OZN o zemljepisnih imenih in slovenski standard SIST ISO 3166 kot priporočilni dokumenti.

\section{RESOLUCIJE ORGANIZACIJE ZDRUŽENIH NARODOV O ZEMLJEPISNIH IMENIH}

Pomembna sestavina zemljevidov so zemljepisna imena. Vsa imena delimo na občna in lastna imena. Občna imena, na primer reka, gora in mesto, pišemo z malo začetnico, lastna imena, na primer Sava, Triglav in Ljubljana, pa z veliko začetnico. Lastna imena delimo na imena bitij, na primer imena oseb in živali, stvarna imena, na primer imena ustanov in umetnostnih del, ter zemljepisna imena. Izraz zemljepisno ime ima še tri približne sopomenke: geografsko ime, krajevno ime in toponim (grško tópos 'kraj' in ónyma, narečna različica od ónoma 'ime'). Veda, ki se ukvarja z zemljepisnimi imeni, se imenuje toponomastika oziroma toponimika. Celoto vseh zemljepisnih imen na svetu $\mathrm{v}$ vseh jezikih delimo na endonime in eksonime. Endonim (grško éndon 'znotraj') je zemljepisno ime nekega pojava v enem od jezikov, ki se govorijo na ozemlju tega pojava, eksonim (grško éksō 'zunaj') pa je zemljepisno ime nekega pojava $\mathrm{v}$ enem od jezikov, ki se ne govorijo na ozemlju tega pojava, če se razlikuje od endonima tega pojava. Poenostavljeno rečeno je endonim domače, izvirno ime zemljepisnega pojava, eksonim pa tuje ime istega pojava. Kadar je neko zemljepisno ime uzakonil ali kako drugače uveljavil oblastni organ območja, kjer je to zemljepisno ime, govorimo o standardiziranem zemljepisnem imenu (Kladnik, Perko 2002).

Slovenski endonimi so slovenska zemljepisna imena znotraj slovenskega etničnega ozemlja, slovenski eksonimi pa slovenska zemljepisna imena na vseh ostalih ozemljih, če se razlikujejo od endonimov na teh ozemljih. Tako je Ljubljana slovenski endonim in Laibach nemški eksonim za glavno mesto Slovenije, Dunaj pa slovenski eksonim in Wien nemški endonim za glavno mesto Avstrije. Na drugi strani London ni slovenski eksonim za angleški London, saj se slovenski zapis tega zemljepisnega imena kljub drugačni izgovarjavi ne razlikuje od zapisa $\mathrm{v}$ angleškem jeziku. Med slovenske eksonime $\mathrm{v}$ ožjem pomenu spadajo le slovenska zemljepisna imena, ki se povsem razlikujejo od izvirnih endonimov, na primer Nemčija za Deutschland ali Carigrad za 
Istanbul, $\mathrm{v}$ širšem pomenu pa tudi zemljepisna imena, prevedena v slovenščino, na primer Skalno gorovje za Rocky Mountains ali Rumena reka za Huang $H e$, podomačena oziroma poslovenjena zemljepisna imena, na primer Pariz za Paris ali Avstralija za Australia, umetna zemljepisna imena, ki nimajo ustrezne izvirne oblike, na primer Panonska kotlina ali Amazonsko nižavje, ter različne kombinacije prevedenih, podomačenih, umetnih in izvirnih zemljepisnih imen, na primer Nova Zelandija za New Zealand, pri kateri je prva beseda prevedena in druga podomačena, ali Novi južni Wales za New South Wales, pri katerem sta prvi besedi prevedeni, tretja beseda pa je del izvirnega endonima.

Mednarodno dejavnost na področju zemljepisnih imen usmerja Organizacija združenih narodov, ki je v prejšnjem stoletju organizirala sedem konferenc o zemljepisnih imenih (United nations conference on the standardization of geographical names), na katerih so sprejeli kar 167 resolucij. Leta 1959 je ustanovila Strokovno skupino Združenih narodov za zemljepisna imena (United nations group of experts on geographical names), ki je imela v prejšnjem stoletju dve srečanji, leta 1960 in 1966, ter dvajset zasedanj, prvo leta 1967 in zadnje leta 2000. Strokovni skupini pomaga 22 regionalnih jezikovno-geografskih oddelkov. Slovenija, ki sodeluje v Oddelku za vzhodno srednjo in jugovzhodno Evropo (East Central and South-East division), je v Ljubljani leta 1999 organizirala petnajsti sestanek in leta 2001 šestnajsti sestanek svoje jezikovno-geografske skupine. V Sloveniji za zemljepisna imena skrbi Komisija za standardizacijo zemljepisnih imen Vlade Republike Slovenije, ki ima sedež na Geografskem inštitutu Antona Melika ZRC SAZU. Sestavljajo jo strokovnjaki s področja geografije, kartografije, jezikoslovja in zgodovine ter predstavniki pristojnih ministrstev.

Ko je Slovenija leta 1992 vstopila v Organizacijo združenih narodov, se je obvezala, da bo spoštovala tudi resolucije o zemljepisnih imenih, ki državam priporočajo, da na splošnih zemljevidih uporabljajo endonime in le izjemoma eksonime. Na tematskih kartah je uporaba eksonimov svobodnejša. S slovenskega gledišča to pomeni, da naj bi druge države slovenske endonime, torej slovenska zemljepisna imena v Sloveniji, zapisovale tako, kot se pišejo $\mathrm{v}$ slovenskem jeziku, torej tudi s šumevci č, š in ž, prav tako pa naj bi Slovenija na svojih zemljevidih pravilno zapisovala tuje endonime, in tako pokazala spoštovanje do pisav in jezikov drugih narodov. Zemljepisna imena so namreč podobna našim osebnim imenom in priimkom, za katera želimo, da jih po celem svetu zapisujejo enako, torej kot je prav. Kaj pomeni potujčevanje priimkov, je znano tudi iz slovenske zgodovine.

Vsaka članica OZN naj bi pripravila pravila za pisanje zemljepisnih imen na njenem ozemlju, vendar jih večina držav še ni, zato pri pisanju zemljepisnih imen vlada velika zmeda. Slovenska Komisija za standardizacijo zemljepi- 
snih imen je leta 2001 za OZN pripravila Concise Gazetteer of Slovenia (Zgoščeni imenik zemljepisnih imen Slovenije), ki temelji na resolucijah sedmih konferenc Združenih narodov za standardizacijo zemljepisnih imen (Ženeva 1967, London 1972, Atene 1977, Ženeva 1982, Montréal 1987 ter New York 1992 in 1998), še posebej na resolucijah I/4 (Nacionalni imeniki zemljepisnih imen), II/17 (Posvetovanje pri pripravi imenikov zemljepisnih imen), II/35 (Začasni spiski standardiziranih imen), III/2 (Označevanje mednarodnih imenikov zemljepisnih imen držav), IV/18 (Večstransko obravnavanje toponimskih podatkov) in V/16 (Izdajanje uradnih nacionalnih oblik zemljepisnih imen). Imenik vsebuje slovenska zemljepisna imena na zemljevidu Republike Slovenije v merilu $1: 1.000 .000$. Vsa zemljepisna imena znotraj ozemlja Republike Slovenije je leta 2001 standardizirala Komisija za standardizacijo zemljepisnih imen slovenske vlade (Perko 2001b).

Največ težav pri zapisovanju zemljepisnih imen na zemljevidih povzročajo nekdanje kolonialne in sovjetske države, saj pogosto poznamo le približne zapise njihovih izvirnih zemljepisnih imen $\mathrm{v}$ enem od kolonialnih jezikov oziroma ruščini. Še vedno ni rešeno vprašanje, kako v latinici zapisati zemljepisna imena, ki so v izvirniku zapisana $\mathrm{z}$ drugimi abecednimi, zlogovnimi ali slikovnimi pisavami. Prevedbo zemljepisnih imen v latinico imenujemo latinizacija. Ločimo transliteracijo in transkripcijo. Pri transliteraciji ali prečrkovanju isti znak izvirne pisave vedno zamenjamo $\mathrm{z}$ istim latiničnim znakom, pogosto kombiniranim s pikico, črtico, vijugico ali drugim razlikovalnim (diaktričnim) znamenjem nad ali pod črko, pri transkripciji pa glasovne prvine izvirnega jezika zapišemo tako, da je izgovor zapisa $\mathrm{v}$ ciljnem jeziku čim bližje izgovoru v izvirnem jeziku. To pomeni, da se glasovno prevedeni zapisi istega izvirnega zemljepisnega imena v več jezikih lahko razlikujejo. Tako je za rusko reko Печора slovenska transkripcija Pečora, angleška Pechora in nemška Petschora. Pri latinizaciji svojih zemljepisnih imen sta se, na primer, Rusija in Jugoslavija odločili za transliteracijo, Kitajska in Japonska pa za transkripcijo, prirejeno angleški izgovorjavi.

Zapisovanje zemljepisnih imen pa je povezano še s celo vrsto drugih kartografskih, jezikovnih, geografskih in celo političnih težav.

Slovenski kartografi morajo pri svojem delu upoštevati tudi Slovenski pravopis 2001, Slovar toponimske terminologije (Radovan 1995a), Toponimska navodila za Slovenijo (Radovan 1995b) in Pravopisno ustrezen zapis zemljepisnih in stvarnih lastnih imen $\mathrm{v}$ Registru zemljepisnih imen in Registru prostorskih enot (Furlan, Gložančev, Šivic-Dular 2001). 


\section{SLOVENSKI STANDARD SIST ISO 3166}

Za standarde na svetovni ravni skrbi International Organization for Standardization (Mednarodna organizacija za standardizacijo), pri nas pa Slovenski inštitut za standardizacijo, ki je leta 1996 izdal slovenski standard SIST ISO 3166 z naslovom Kode za predstavljanje imen držav in drugih ozemelj, ki vsebuje tudi standardizirana imena držav.

Slovenski standard loči tri različice imen držav: neuradno ime, uradno kratko ime in uradno polno (dolgo) ime države (Perko 1996a, 1996b). Neuradna slovenska imena držav so v celoti povzeta po predlogu Komisije za standardizacijo zemljepisnih imen, uradna kratka in uradna polna imena pa temeljijo na tem predlogu ter prevodu izvirnih predlogov imen držav v angleškem in francoskem jeziku, kakor so jih za mednarodni standard Organizaciji združenih narodov predlagale države same. Kot primer poglejmo Slovenijo, Rusijo in Libijo: neuradna imena so Slovenija, Rusija in Libija, uradna kratka imena Slovenija, Ruska federacija in Libijska arabska džamahirija, uradna polna imena pa Republika Slovenija, Ruska federacija in Socialistična ljudska libijska arabska džamahirija. Pri večini držav je neuradno ime države enako uradnemu kratkemu imenu države.

Pri neuradnih slovenskih imenih držav je Komisija za standardizacijo zemljepisnih imen upoštevala pravila slovenskega pravopisa o pisanju tujih zemljepisnih in tujih osebnih imen $\mathrm{v}$ slovenskem jeziku, ki jih poenostavljeno lahko zapišemo:

- pravilo: imena držav slovenimo (podomačujemo),

- pravilo: znana zemljepisna in osebna imena slovenimo,

- pravilo: manj znana zemljepisna in osebna imena ohranjamo v izvirni

obliki (izvirnik za latinične pisave, transliteracija (prečrkovanje) za

nelatinične pisave).

Iz teh treh pravil je komisija želela določiti eno samo, preprosto, razumljivo, sistematično in nedvoumno pravilo, ki naj bi brez izjeme veljalo za zapis vseh držav v slovenskem jeziku. To pravilo se glasi: Imena držav v slovenskem jeziku slovenimo, $v$ izvirni obliki pa obdržimo le tiste sestavne dele imen držav, ki so osebna imena ali manj znana zemljepisna imena. Pri pridevniški rabi osebnih imen uporabljamo svojilno obliko. Tako so imena držav $\mathrm{v}$ celoti slovenjena, ostali pa sta dve imeni po manj znanih zemljepisnih imenih in še osem imen držav po osebah, kamor je komisija prištela tudi imena svetnikov, saj za manj znana svetniška imena nimamo ustreznih slovenskih imen, nesistematično pa bi bilo, če bi nekatera imena slovenili, druga pa ne. Državi, ki imata v svojem imenu manj znano zemljepisno ime, sta Gvineja Bissau, ki je dobila ime po mestu Bissau in ima prvi del imena slovenjen, drugi 
del pa v izvirni obliki, ter Sierra Leone, ki ima ime po gorovju Sierra Leone in ima oba dela imena neslovenjena.

Po svetnikih, ki jih obdržimo v izvirni obliki, ima ime pet držav: Saint Kitts in Nevis, Saint Lucia, Saint Vincent in Grenadine, San Marino ter São Tomé in Príncipe. Svojilna oblika osebnega imena je del imena pri treh državah: Marshallovi otoki, Salomonovi otoki in Saudova Arabija. Pri imenih držav po pomembnih rodbinah se je komisija odločila za slovenjenje, torej za Luksemburg in Lihtenštajn, čeprav bi do neke mere tudi imena rodbin lahko šteli med osebna imena in jih pisali v izvirniku. Pisava Lihtenštajna v slovenjeni obliki je edina prava novost, ki jo je sprejela komisija. Pri ostalih imenih je komisija le izbrala tiste obstoječe različice imen, ki so ustrezale sprejetemu pravilo. Izmed različic za Centralnoafriško oziroma Srednjeafriško republiko in Kapverdske oziroma Zelenortske otoke se je komisija odločila za bolj slovensko različico, torej Srednjeafriško republiko in Zelenortske otoke. Pri državah nekdanje Sovjetske zveze v srednji Aziji se je komisija odločila za končnico -stan in ne končnico -ija, torej za Kazahstan, Kirgizistan, Tadžikistan, Turkmenistan in Uzbekistan, podobno kot to velja za sosednji državi Afganistan in Pakistan, ki spadata v isti kulturni krog. Komisija je ugotovila, da ni razloga, da bi za Hrvaško uporabljali iz hrvaškega jezika sposojeno Hrvatsko, ali da bi za Moldavijo uporabljali romunsko ime Moldova.

Uradna polna imena držav razdelimo na več skupin. V prvi skupini uradnih polnih imen nastopa kratko ime države kot samostalnik: na primer slovensko Republika Slovenija in angleško Republic of Slovenia, slovensko Država Izrael in angleško State of Izrael, slovensko Kraljevina Belgija in angleško Kingdom of Belgium, slovensko Republika Južna Afrika (nikakor pa ne Južnoafriška republika) in angleško Republic of South Africa, slovensko Zveza Bahami in angleško Commonwealth of Bahamas ter podobno. V drugi skupini nastopa kratko ime države kot pridevnik: na primer slovensko Francoska republika in francosko République Française, slovensko Češka republika in češko Česká Republika, slovensko Portugalska republika in portugalsko República Portuguesa, slovensko Ruska federacija in rusko Rossijskaja federacija, slovensko Gabonska republika in francosko République Gabonaise, in podobno. V tej skupini je le 12 držav. V tretji skupini so države, ki imajo kratko ime enako polnemu imenu: na primer Barbados, Eritreja, Irska, Romunija in podobno.

Ker lahko vsaka država v vsakem trenutku poljubno spremeni svoje uradno kratko ali uradno dolgo ime, s čimer pa se morajo strinjati ostale države, članice OZN, standard ISO 3166 ni nekaj dokončnega, ampak se spreminja glede na spremembe, ki jih prijavljajo posamezne države. Tako Grčija Makedoniji ne dovoli uporabljati njenega imena Makedonija, ki je zato morala kot uradno polno ime prijaviti Nekdanja jugoslovanska republika Makedonija. Že 
leta 1996, takoj po izidu slovenskega standarda, so svoje uradno polno ime spremenile države Afganistan, Gvajana, Vatikan in Avstralija: Afganistan iz Republika Afganistan v Islamska država Afganistan, Gvajana iz Kooperativna republika Gvajana v Republika Gvajana, Vatikan iz Vatikanska mestna država (Sveti sedež) v Sveti sedež (Vatikanska mestna država), Avstralija pa iz Zveza Avstralija v samo Avstralija, tako da ima enako neuradno, uradno kratko in uradno polno ime. V naslednjih letih je bilo nekaj manj sprememb.

Čeprav je tudi standard SIST ISO 3166 "samo" priporočilo, pa neupoštevanje lahko privede do resnih problemov. Tako je, na primer, Kitajska od Vlade Republike Slovenije zahtevala prepoved prodaje knjige ene od naših največjih založb, ker imena držav v tej knjigi niso bila zapisana po standardu. Kitajsko je motil nestandardizirani zapis uradnega imena za Tajvan.

\section{ZAKON O AVTORSKI IN SORODNIH PRAVICAH}

Vse večji problem pri zemljevidih je spoštovanje avtorskih pravic. Nespoštovanje pa ni povezano samo $\mathrm{z}$ moralnimi vprašanji, ampak tudi s hudimi materialnimi posledicami za kršitelja.

Za pravilno določanje avtorstva in vrednotenje kartografskega dela je nujno poznavanje njegovega poteka ter njegove sestavljenosti in prepletenosti. Pri izdelavi tematske karte, $\mathrm{s}$ katero se raziskovalci najpogosteje srečujemo, lahko v grobem ločimo tri sklope oziroma stopnje: znanstveno, znanstveno-umetniško in tehnološko, pri izdelavi splošne karte pa običajno le dve: znanstveno-umetniško in tehnološko stopnjo. Končni zemljevid je tako rezultat dela več sodelavcev, zato ima običajno več avtorjev.

Prva, znanstvena stopnja izdelave tematska karte obsega pripravo vsebine (tematike) karte, kar je v celoti naloga raziskovalca. Končni rezultat te stopnje je tako imenovani avtorski original karte, ki je enakovreden pripravi članka, še posebej v geografiji, geodeziji in nekaterih drugih prostorskih strokah, kjer je objava nekaterih znanstvenih in strokovnih dognanj na zemljevidih pogosto celo bolj nazorna kot predstavitev v pisni obliki, pogosto pa se celo zgodi, da nekaterih znanstvenih dognanj, ki se vežejo na prostorsko opredelitev, skoraj ni mogoče ustrezno predstaviti drugače kot na zemljevidih. Na avtorskem originalu so lahko predstavljeni izsledki le enega terenskega opazovanja ali pa večdesetletnega znanstvenega dela. Avtorja tega sklopa običajno opredelimo kot avtorja vsebine zemljevida. Lahko bi mu rekli tudi kartograf tematik.

Druga, znanstveno-umetniška stopnja obsega predvsem izdelavo idejnega in glavnega projekta karte, analizo in pripravo tematske vsebine oziroma avtorskega originala, ki ga je pripravil raziskovalec na prvi stopnji, za prikaz na karti, izdelavo kartografskega redakcijskega načrta s teoretično-matematično 
osnovo, vsebinsko zasnovo, pripravo metod kartografske generalizacije, izbiro metod prikaza geografskih in tematskih elementov vsebine, zasnovo kartografskega oblikovanja kartografskih izraznih sredstev in izdelavo legende znakov z upoštevanjem znanstvenih in estetskih meril. Avtor tega sklopa je kartograf redaktor.

Tretja, tehnološka oziroma tehnično-izvajalska stopnja obsega predvsem kartografsko-tehnično izdelavo karte $\mathrm{z}$ modeliranjem vsebine $\mathrm{z}$ metodami kartografske generalizacije in oblikovanjem kartografskega prikaza s posebnimi kartografskimi računalniškimi orodji ter računalniška priprava za reprodukcijo karte oziroma objavo na različnih medijih (na primer tisk, medmrežje, zgoščenka). Avtorju tega sklopa običajno rečemo kartograf izvajalec.

Pri delu na prvih dveh stopnjah torej prevladujejo znanstvene prvine, na tretji stopnji pa tehnološke.

Zakon o avtorski in sorodnih pravicah v 11. podčlenu 5. člena varuje avtorstvo "pravega" kartografa oziroma "kartografsko maniro", to je kartografa redaktorja in kartografa izvajalca (iz druge in tretje stopnje kartografskega dela), v nekaterih drugih podčlenih 5. člena pa avtorja vsebine karte, to je raziskovalca (Trampuž, Oman, Zupančič 1997).

Zakon kršimo tako rekoč vsi po vrsti. Zemljevidi, ki prihajajo z geografskih ustanov, pogosto niso opremljeni $\mathrm{z}$ avtorstvom, ali pa so navedeni le nekateri avtorji, in še to največkrat napačno glede na prej omenjene sklope. Še bolj je nenavajanje ali nepravilno navajanje avtorjev sporno pri izdajah založb, saj gre za tržne ustanove. Tudi v trenutno veljavnem sistemu COBISS so vsa kartografska dela oziroma vse stopnje kartografskega dela opredeljene le z eno oznako, to je 4.17, kar vnaša nepopisno zmedo, saj so ponekod pod to oznako zavedeni raziskovalci, to je avtorji vsebine zemljevida, ponekod kartografi redaktorji, ponekod pa celo kartografi izvajalci. Oznake v skupini 4 pomenijo sekundarno avtorstvo. Sem so poleg kartografov uvrščeni še na primer uredniki, prevajalci in prireditelji, kar kaže na precejšnje nepoznavanje kartografskega dela. Pravi avtorji zemljevidov so zakriti, pogosto so navedeni napačni avtorji, ali pa nekateri avtorji izpuščeni.

Za razrešitev tega problema smo oktobra 2002 na Geografskem inštitutu Antona Melika ZRC SAZU in Geodetskem inštitutu Slovenije pripravili skupen predlog vrednotenja oziroma delitve kartografskega dela, ki upošteva trojno avtorstvo zemljevidov in sledi Zakonu o avtorski in sorodnih pravicah, novembra 2002 pa smo ga uskladili z Inštitutom za informacijske znanosti, ki skrbi za COBISS. Na ta način poskušamo poenotiti zapisovanje avtorjev na zemljevidih.

Za številne zlorabe in kršenje zakona, predvsem pri založbah, pa smo geografi v pravnem smislu največkrat krivi sami, saj podpisujemo slabo sestavljene pogodbe, $\mathrm{s}$ katerimi se sami nevede odrečemo nekaterim pravicam, ki nam 
jih sicer ponuja Zakon o avtorski in sorodnih pravicah. Tako ne škodujemo samo sebi in ustanovam, $\mathrm{s}$ katerih prihajamo, ampak tudi geografiji

\section{SKLEP}

Čeprav je slovenska tematska kartografija, tudi kot aplikacija znanosti, konec 20. stoletja po osamosvojitvi države doživela precejšen razcvet, $h$ kateremu so največ prispevale prav geografske ustanove, pa se številni problemi kartografije niso rešili. Med večjimi problemi je tudi neupoštevanje obvezujočih in priporočilnih dokumentov, ki posegajo na področje kartografije. V Sloveniji so za kartografe pomembni predvsem Zakon o avtorski in sorodnih pravicah, resolucije OZN o zemljepisnih imenih in slovenski standard SIST ISO 3166.

Nekatere probleme bomo morali rešiti geografi sami ali v sodelovanju z drugimi strokovnjaki, predvsem kartografi, nekatere bo rešila država, reševanje nekaterih problemov tematske kartografije pa bo, podobno kot na mnogih drugih področjih, pospešil vstop Slovenije v Evropsko zvezo.

\section{Viri in literatura:}

Čarni, A., Marinček, L., Seliškar, A., Zupančič, M. (prireditelji) 2002. Vegetacijska karta gozdnih združb Slovenije v merilu $1: 400.000$. Ljubljana, Založba ZRC.

Fridl, J., Kladnik, D., Orožen Adamič, M., Perko, D. (uredniki) 1998. Gegrafski atlas Slovenije. Ljubljana, DZS, 360 strani.

Fridl, J., Kladnik, D., Orožen Adamič, M., Perko, D., Zupančič, J. (uredniki) 2001. National Atlas of Slovenia. Ljubljana, Rokus, 192 strani.

Furlan, M., Gložančev, A., Šivic-Dular, A. 2001. Pravopisno ustrezen zapis zemljepisnih in stvarnih lastnih imen $v$ Registru zemljepisnih imen in Registru prostorskih enot. Ljubljana, Geodetska uprava Republike Slovenije, 58 strani.

Kladnik, D., Perko, D. 2002. Tuja geografska imena. V: Družinski atlas sveta, Ljubljana, Slovenska knjiga, str. 219-220.

Marinček, L., Čarni, A. 2002. Komentar k vegetacijski karti gozdnih združb Slovenije v merilu 1 : 400.000. Ljubljana, Založba ZRC, 120 strani.

Natek, M., Perko, D. 1999. 50 let Geografskega inštituta Antona Melika ZRC SAZU. Geografija Slovenije 1. Ljubljana, Založba ZRC, 176 strani.

Perko, D. 1996a. Sporna imena držav v slovenskem jeziku. Geografski obzornik 43-3. Ljubljana, str. 20-27. 
Perko, D. 1996b. Standardizirana imena držav v slovenskem jeziku. Geografski obzornik 43-4. Ljubljana, str. 18-26.

Perko, D. 2001a. Analiza površja Slovenije s stometrskim digitalnim modelom reliefa. Geografija Slovenije 3. Ljubljana, Založba ZRC, 230 strani.

Perko, D. 2001b. Concise gazetteer of Slovenia (Zgoščeni imenik zemljepisnih imen Slovenije). United Nations Series of National Gazetteers: Slovenia. Ljubljana, Geodetska uprava Republike Slovenije, 48 strani.

Radovan, D. 1995a. Slovar toponimske terminologije. Ljubljana, Geodetska uprava Republike Slovenije, 40 strani.

Radovan, D. 1995b. Toponimska navodila za Slovenijo. Ljubljana, Geodetska uprava Republike Slovenije, 30 strani.

Rajšp, V. (urednik) 2001. Slovenija na vojaškem zemljevidu 1763-1787. 7 del. Ljubljana, Založba ZRC, 132 strani.

Slovenski pravopis 2001. Ljubljana, Založba ZRC, 1808 strani.

Slovenski standard SIST ISO 3166:1996. Ljubljana, Urad za standardizacijo in meroslovje pri Ministrstvu za znanost in tehnologijo, 52 strani.

Smith, C. D. 1987. Cartography in the prehistoric period of the old world: Europe, the Middle East and North Africa. The history of cartography 1: Cartography in prehistoric, ancient, and medieval Europe and Mediterranean. Chicago, London, str. 54-101.

Šolska karta Slovenije 1:500.000. Geodetski zavod Slovenije in Založba Mladinska knjiga. Ljubljana, 1997.

Šolska karta Sveta 1: 70.000.000. Freytag-Berndt, Geodetski zavod Slovenije in Založba Mladinska knjiga. Ljubljana, 1999.

Trampuž, M., Oman, B., Zupančič, A. 1997. Zakon o avtorski in sorodnih pravicah s komentarjem. Ljubljana, Gospodarski vestnik, 472 strani.

\section{THEMATIC CARTOGRAPHY AS A GEOGRAPHICAL APPLICATION}

\section{Summary}

Cartography is an auxiliary branch of geography. Its primary product, maps, combines elements of science and art. Maps are divided into the general and the specific. On general maps or topographical charts, all the elements or contents are shown relatively equally, while on specific maps or thematic charts, certain elements are stressed and others are left out.

Thematic maps are especially important for geography since they assist geographers in their research work and enable the most graphic presentation of 
their research results. They also permit geography teachers to transfer knowledge to students more easily. A thematic map may thus be a geographical tool in itself or the basis for some other geographical work.

Institutionalized Slovene cartography began on February 7, 1952, with the establishment of the Cartography Institute, which is now the Department of Thematic Cartography at the Anton Melik Geographical Institute of the Scientific Research Centre of the Slovenian Academy of Sciences and Arts. The development of Slovene thematic cartography accelerated considerably following the independence of the country in 1991 as the need for thematic maps increased greatly. During the 1990 's, government and private institutions cofinanced many extensive and fundamental geographical projects, which resulted in the publication of monographs containing numerous thematic maps. From the viewpoint of content and technology, the greatest achievements in Slovene thematic cartography are the Geographical Atlas of Slovenia, which is widely employed in various fields, and the National Atlas of Slovenia, which is an outstanding achievement at the international level and of great significance for the promotion of Slovenia and Slovene geography and cartography abroad. The Slovene geography textbooks published in the late 1990's are very richly furnished with maps as well.

This rapid development, however, did not eliminate various problems in Slovene thematic cartography, issues that are important to geographers in general. The major problems, for example, include the education, employment, and financing of cartographers, the cooperation and coordination of geographical, geodetic, and related institutions in this field, the linking of geographical information systems with digital thematic cartography, the use of thematic maps in scientific theses, books, textbooks, other publications, and on the internet, and the scientific review and cost analysis of producing copyright maps and final maps. An increasingly prominent issue is the consideration or rather the ignoring of various Slovene and international conventions for the preparation of maps including United Nations resolutions, international and Slovene standards (SIST ISO), and copyright laws.

As in many other fields, resolving the issues in thematic cartography will facilitate Slovenia's entry into the European Union. 